\title{
Improved survival for non-Hodgkin lymphoma patients in New South Wales, Australia
}

\author{
Xue Q Yu*1, Wendy H Chen² and Dianne L O'Connell1
}

\begin{abstract}
Background: We evaluated if the survival benefit of adding rituximab to standard chemotherapy for non-Hodgkin lymphoma (NHL) observed in clinical trials has been experienced by an Australian NHL patient population.

Methods: NHL cases diagnosed in 1985-2004 in New South Wales (NSW) were followed-up to the end of 2004. Rituximab prescription data were obtained from Medicare Australia. Using a Poisson regression model adjusted for age group, sex, NHL subtype and time period (1990-1994, 1995-1999 and 2000-2004), we estimated excess risk of death after a diagnosis of NHL. To give context to the survival trend, trends in incidence and mortality were also estimated.

Results: Compared with 1990-1994, after adjusting for age, sex and NHL subtype the relative excess risk of death was significantly lower $(p<0.0001)$ in 1995-1999 (0.89) and 2000-2004 (0.74). A sharp fall in mortality was observed from 2000 to 2004 (annual percentage change $(A P C)=-4.7, p=0.009$ ), while a small but significant rise in incidence was seen from 1990 to 2004 ( $A P C=0.5, p=0.01$ ). The number of times rituximab was dispensed in NSW increased rapidly from 1274 in 1999 to 9250 in 2004.

Conclusion: It is likely that some benefit of adding rituximab to the standard chemotherapy for NHL has been experienced at the population level.
\end{abstract}

\section{Background}

The incidence of non-Hodgkin lymphoma (NHL) had increased substantially in recent decades with smaller increases in recent years in many western countries including Australia. The mortality for NHL rose at a similar rate, stabilised in the early 1990 s and then started to fall at the end of the 1990s. The survival pattern for NHL had not changed significantly in over two decades up to the late 1990s [1] despite attempts to increase the efficacy of the standard treatment, combination chemotherapy (CHOP), with the addition of other cytotoxic drugs [2]. Two pivotal clinical trials in the late 1990s showed that the addition of the monoclonal antibody targeting the CD20 antigen expressed on almost all malignant B cells, rituximab, to standard chemotherapy regimens improved the survival for patients with indolent NHL, and patients with diffuse large B-cell lymphoma (the two commonest NHL subtypes) [1].

\footnotetext{
* Correspondence: xueqiny@nswcc.org.au

${ }^{1}$ Cancer Epidemiology Research Unit, Cancer Council New South Wales, 153 Dowling Street, Woolloomooloo, NSW 2011, Australia

Full list of author information is available at the end of the article
}

This revolutionary advance in the treatment of NHL was introduced in Australia in around $2000[3,4]$. The aim of this study was to evaluate if the introduction of this new treatment modality improved the prognosis of NHL patients in the State of New South Wales (NSW), Australia.

\section{Methods \\ Data}

Data were obtained from the population-based NSW Central Cancer Registry, Australia, for cases diagnosed with a single first primary NHL between 1985 and 2004 . Based on population size, NSW is the largest state comprising approximately one-third of the Australian population. Notification of cancer has been a statutory requirement for all NSW public and private hospitals, radiotherapy departments and nursing homes since 1972, and for pathology departments since 1985 [5]. Coding for primary site and NHL subtype was done either by medical coders in the hospitals that notified the Registry, or by medical coders in the Registry, who generally assigned subtype based on pathology and hospital notifications. The proportion of cases that were histologically verified 
has been relatively constant (>85\%) since 1985 [5]. Cases aged less than 15 years old, or those reported to the Registry through death certificate only or first identified at post-mortem were excluded. All eligible cases were matched to death records from the State Registrar of Births, Deaths and Marriages and the National Death Index to determine survival status at 31 December 2004.

We obtained the Pharmaceutical Benefits claims data representing the number of times rituximab was dispensed including original prescriptions and repeats [6] in NSW for 1999-2004 from the Medicare Australia website. The prescription codes for NHL patients only were used (8293L, 8294M, 8665C and 8666D), so any increase in the number of claims is directly related to an increase in use for the treatment of NHL. As rituximab was listed for subsidisation in mid 1998, we did not include claims data for that year.

\section{Trends in survival}

Relative survival, a means of removing the effect of mortality from other causes [7], was used in this study because causes of death on death certificates are often inaccurate [8]. Relative survival is the ratio of the observed proportion surviving in a group of patients to the expected proportion that would have survived in a comparable group of people (with the same distribution by age and sex) from the general population [9].

Observed survival was estimated by the life table method [10]. The estimates of the expected survival proportions for each time period (1990-94, 1995-99 and 2000-2004) were derived from the life tables for the general population based on all-cause mortality data and the NSW population by (five-year) age group, sex and calendar year obtained from the Australian Bureau of Statistics. The period method [11] was used to estimate fiveyear relative survival for the time periods 1990-1994, 1995-1999, and 2000-2004 using the implementation suggested by Paul Dickman [12]. Period analysis applies left truncation to retain the survival experience seen in the period of interest only [11] (in this case, 1990-94, 1995-99 and 2000-2004).

As treatments for NHL depend on histological subtypes [13] and there are approximately 40 different subtypes [14], we grouped all subtypes into four broad groups according to the cell of origin as well as their response to therapy and overall survival. They are "aggressive B-cell", "indolent B-cell", "other NHL (mainly T/NK cells)" and "NHL not otherwise specified (NOS)". The clinical groups were based on the WHO classification for lymphoma [15] and the International Classification of Disease-Oncology Third Edition (ICD-O-3) [16]. Cases diagnosed in 1985-2001 were coded according to ICD-O-2 [17] in the registry; a computer program converted the ICD-O-2 morphology codes into ICD-O-3 morphology codes using a trans-coding table [16]. Cases diagnosed after 2001 were coded in ICD-O-3 in the registry.

Changes in survival over time may be due to several factors, so we assessed the effect of period of survival using multivariable analysis to adjust for confounding variables [18]. More detailed statistical analysis methods for relative survival modeling can be found on Paul Dickman's website http://www.pauldickman.com/. Briefly, we estimated the relative excess risk of death (RER) due to cancer for the 3 periods with 1990-1994 being the reference period, assuming a Poisson distribution for excess deaths $[19,20]$. In the Poisson model, the dependent variable was the number of excess deaths (calculated as the observed number of deaths minus the expected number of deaths based on the population death rates) with explanatory variables being period of survival, age group at diagnosis (15-44, 45-59, 60-74 and 75+ years), sex, year of follow-up and subtypes of NHL, and the natural logarithm of the population size as the offset. All explanatory variables included in the model were categorical. The RER derived from this model is the ratio of the excess risk of death in a given period to the reference period of 19901994 after controlling for the other factors included in the model. A RER smaller than one for a given period indicated that the risk in that period was lower than that for 1990-1994 and vice versa. Ninety-five percent confidence intervals (CIs) for the RERs were calculated using the estimated coefficients and standard errors from the Poisson model. A two-sided, $\log$-likelihood ratio test with $\mathrm{p}<$ 0.05 was taken to indicate statistical significance.

All analyses were conducted using SAS version 9.0, and the procedure GENMOD was used to fit the models and assess the prognostic effects of the variables on relative survival.

\section{Trends in incidence and mortality rates}

To estimate trends in incidence and mortality for NHL, which we report as context for the survival trend, annual age-sex standardised incidence and mortality rates were calculated for the NSW resident population for 1990 to 2004 . These rates were expressed per 100,000 of the population and age and sex adjusted by the direct method to the 2001 Australian standard population.

Joinpoint regression analysis [21] was used to identify points where a distinct change in the direction or steepness of the trends occurred. The software [22] takes trend data and fits the simplest joinpoint model that the data allows. The analysis starts with the minimum number of joinpoints and identifies any distinct change in direction in the rates and then tests whether the changes are statistically significant. To describe linear trends by period, an annual percent change (APC) is computed for each of those trends. 


\section{Results}

A total of 18,798 NHL cases were diagnosed in 19902004 , with the commonest subtypes being diffuse large Bcell lymphomas (DLBCL) (5022) followed by small lymphocytic lymphoma (SLL)/chronic lymphocytic leukemia (CLL) (3929). Table 1 shows the NHL subtypes and main groups and their ICD-O-3 codes.

Table 2 shows the characteristics of the NHL patients by calendar period.

There was a substantial increase in 5-year relative survival for patients with NHL from 1990-1994 to 2000-2004 $(53.3 \%$ vs $62.1 \%)$ (Table 3$)$. Compared with the survival experience of patients in 1990-94, relative excess risk of death was significantly lower $(\mathrm{p}<0.0001)$ in 1995-99
$($ RER $=0.89,95 \%$ CI: 0.84-0.94 $)$ and 2000-2004 $(\mathrm{RER}=$ 0.74, 95\% CI: 0.69-0.78) after adjusting for age, sex and NHL subtype. Table 3 also shows the estimated 5-year relative survival and relative excess risk of death for levels of the other covariates included in the Poisson model.

Five-year relative survival in 2000-2004 was higher for all age groups with those very old (75+ years) having poorer outcomes (Figure 1)

Five-year relative survival in 2000-2004 was higher for all subtypes except for 'Other NHL' (Figure 2).

The number of times rituximab was dispensed for the treatment of NHL increased rapidly from 1999 (1274) to 2004 (9250) in NSW (Figure 3).

Table 1: Number of cases by subtype of non-Hodgkin lymphoma with groups according to the WHO classification, 19902004 NSW, Australia.

\begin{tabular}{|c|c|c|}
\hline Subtypes and groups & ICD-0-3 codes & No. of cases \\
\hline \multicolumn{3}{|l|}{ Aggressive B-cell lymphomas } \\
\hline Follicular lymphoma, grade 3 & 9698 & 179 \\
\hline $\begin{array}{l}\text { Malignant lymphomas (ML), mixed small } \\
\text { \& large cell, diffuse }\end{array}$ & 9675 & 466 \\
\hline Diffuse large B-cell lymphoma & $9678-9680,9684$ & 5022 \\
\hline Burkitt's lymphoma & 9687,9826 & 179 \\
\hline Lymphoblastic lymphoma & 9728,9836 & 11 \\
\hline \multicolumn{3}{|l|}{ Indolent B-cell lymphomas } \\
\hline Follicular lymphomas (grade 1 and 2) & 9690-9691, 9695 & 2558 \\
\hline $\begin{array}{l}\text { Marginal zone lymphoma of mucosa- } \\
\text { associated lymphoid tissue (MALT) }\end{array}$ & 9689,9699 & 302 \\
\hline $\begin{array}{l}\text { Small lymphocytic lymphoma, Chronic } \\
\text { lymphocytic leukemia }\end{array}$ & 9670,9823 & 3929 \\
\hline Hairy cell leukemia & 9940 & 277 \\
\hline Lymphoplamacytic lymphomas & 9671,9761 & 472 \\
\hline \multicolumn{3}{|l|}{ Other NHL } \\
\hline $\begin{array}{l}\text { Mature T-cell lymphomas: peripheral, } \\
\text { angioimmunoblastic, hepatosplenic } \\
\text { gamma/delta T-cell }\end{array}$ & $9702,9705,9708,9714,9716,9827$ & 245 \\
\hline Cutaneous T-cell & 9709 & 85 \\
\hline Mycosis fungoides and mantle cell & $9700-9701,9673$ & 422 \\
\hline Other T/NK cell lymphomas & $9717,9718,9719,9831,9948$ & 58 \\
\hline Precursor T-cell & 9729,9837 & 11 \\
\hline \multicolumn{3}{|l|}{ NHL not otherwise specified (NOS) } \\
\hline ML, NOS & 9590 & 1191 \\
\hline ML, non-Hodgkin, NOS & 9591 & 2701 \\
\hline $\begin{array}{l}\text { Precursor cell lymphoblastic lymphoma, } \\
\text { NOS }\end{array}$ & 9727 & 72 \\
\hline Lymphoid leukemia, NOS & 9820 & 566 \\
\hline Immunoproliferative disease, NOS & 9760 & 32 \\
\hline $\begin{array}{l}\text { Precursor cell lymphoblastic leukemia } \\
\text { NOS }\end{array}$ & 9835 & 20 \\
\hline
\end{tabular}


Table 2: Characteristics of patients with non-Hodgkin lymphoma, NSW Australia, 1990-2004.

\begin{tabular}{|c|c|c|c|c|}
\hline & \multirow[t]{2}{*}{ Number of cases } & \multicolumn{3}{|c|}{ Percentage (\%) } \\
\hline & & $\begin{array}{l}1990-1994 \\
(\mathrm{n}=5454)\end{array}$ & $\begin{array}{l}1995-1999 \\
(n=6231)\end{array}$ & $\begin{array}{r}2000-2004 \\
(n=7113)\end{array}$ \\
\hline \multicolumn{5}{|l|}{ Sex } \\
\hline Males & 10,475 & 56.3 & 55.2 & 55.7 \\
\hline Females & 8,323 & 43.7 & 44.8 & 44.3 \\
\hline \multicolumn{5}{|l|}{$\begin{array}{l}\text { Age at diagnosis } \\
\text { (years) }\end{array}$} \\
\hline $15-44$ & 2,484 & 15.2 & 13.2 & 11.7 \\
\hline $45-59$ & 4,110 & 20.5 & 21.8 & 22.9 \\
\hline $60-74$ & 6,905 & 38.0 & 37.1 & 35.4 \\
\hline $75-89$ & 5,299 & 26.3 & 27.9 & 29.9 \\
\hline \multicolumn{5}{|l|}{ NHL groupings } \\
\hline Aggressive B-cell & 5,857 & 32.4 & 33.3 & 28.3 \\
\hline Indolent B-cell & 7,538 & 39.5 & 38.2 & 42.2 \\
\hline Other NHL & 821 & 1.4 & 4.1 & 6.9 \\
\hline NHL NOS & 4,582 & 26.6 & 24.5 & 22.5 \\
\hline
\end{tabular}

The trends in mortality suggested that a small rise from 1990 to 1996 ( $\mathrm{APC}=0.8, \mathrm{p}=0.44$ ) was followed by a substantial but non-significant fall $(\mathrm{APC}=-2.1, \mathrm{p}=0.41)$ from 1996 to 2000 and then a further sharp fall from 2000 to 2004 (APC $=-4.7, \mathrm{p}=0.009$ ). There was a small but significant increase in incidence from 1990 to 2004 (APC $=0.5, \mathrm{p}=0.02)$.

\section{Discussion}

In this population-based study, we found that a substantial improvement in survival for NHL (5-year relative survival $62 \%$ in $2000-2004$ vs $53 \%$ in $1990-1994$ ) coincided with a sharp fall in mortality after 2000 . This was approximately when rituximab was approved by the Australian Therapeutic Goods Administration for clinical use in Australia for the two commonest NHL subtypes, namely low grade or follicular lymphoma (June 1998) [3] and diffuse large B-cell lymphomas (February 2002) [4]. These results are consistent with the beneficial effects of rituximab on cancer survival observed in clinical trials [23-25].

The findings of this population-based study are important because it includes all patients with NHL, many of whom would not have met the trials' inclusion criteria, in a well-defined geographical area, thus reflecting the experience of real world everyday clinical practice. The main strength of the study was that we grouped subtypes of lymphomas into treatment-based categories classified according to WHO guidelines. This grouping has been used by others [26], is clinically useful [27,28] and reduces the probability of misclassification bias [28].
Another strength is that we studied the trends in the incidence of, survival for and mortality from NHL simultaneously, and interpreted the survival trend in the context of incidence and mortality trends, as recommended by several authors [29-31].

What may explain the better survival observed in the most recent period in this study? Several factors may have contributed to the improved survival in 2000-2004. First, high-dose chemotherapy with shorter intervals between treatment cycles [32], together with better supportive care including antibiotics and growth factor to manage myelotoxicity [33], was introduced during the study period. An Australian study has also demonstrated that growth factor can be used safely and efficaciously to support intensified chemotherapy (CHOP-14) in Australian NHL patients [34]. However it only became available in 2003 and it was dispensed 1560 times in NSW in 2004 [6] so is unlikely to explain the improved survival in 20002004. Second, more NHL patients in NSW may have participated in clinical trials [35] which may in part have led to improved survival in the later period. Third, the introduction of highly active antiretroviral therapy in Australia around 1997 [36] may explain in part the improved survival in 2000-2004 [37]. The substantial (although not significant) decline (-2.1\% per year) in mortality from 1996 to 2000 in our data provides further support for this. Fourth, changes in case-mix over time may have accounted for some of the survival benefits observed in 2000-2004. However our use of four broad categories of lymphoma subtype should reduce this problem to a mini- 
Table 3: Five-year relative survival (RSR) and relative excess risk (RER) during the first five years after diagnosis of NHL, NSW Australia 1990-2004.

\begin{tabular}{|c|c|c|c|c|}
\hline & 5-yr RSR (\%) & $\mathrm{RER}^{*}$ & $95 \% \mathrm{Cl} \dagger$ & P-value \\
\hline Period of survival & & & & $<0.0001$ \\
\hline 1990-1994 & 53.3 & 1.00 & & \\
\hline 1995-1999 & 55.9 & 0.89 & $(0.84-0.94)$ & \\
\hline $2000-2004$ & 62.1 & 0.74 & $(0.69-0.78)$ & \\
\hline Sex & & & & $<0.0001$ \\
\hline Males & 57.5 & 1.00 & & \\
\hline Females & 57.5 & 0.86 & $(0.82-0.91)$ & \\
\hline $\begin{array}{l}\text { Age at diagnosis } \\
\text { (years) }\end{array}$ & & & & $<0.0001$ \\
\hline $15-44$ & 66.6 & 1.00 & & \\
\hline $45-59$ & 70.3 & 1.03 & $(0.94-1.13)$ & \\
\hline $60-74$ & 58.3 & 1.56 & $(1.44-1.70)$ & \\
\hline $75-89$ & 39.5 & 2.95 & $(2.71-3.20)$ & \\
\hline NHL grouping & & & & $<0.0001$ \\
\hline Agressive B-cell & 45.2 & 1.00 & & \\
\hline Indolent B-cell & 73.1 & 0.30 & $(0.28-0.32)$ & \\
\hline Other NHL & 61.0 & 0.92 & $(0.86-0.97)$ & \\
\hline NHL NOS & 46.6 & 0.62 & $(0.54-0.71)$ & \\
\hline
\end{tabular}

* Adjusted for all covariates shown in the table using a Poisson regression model

$+\mathrm{Cl}$ - confidence interval

mum [28]. As shown in Table 2 the case-mix in different time periods was generally comparable except for "Other NHL".

Finally, increasing survival over time may reflect improvements in earlier detection by screening programs. However, there is no possibility for early detection of NHL. Indeed, a small and gradual increase in incidence was seen from 1990 to 2004, not a sudden substantial increase in the 2000-2004 period. Therefore, the coincidental sharp fall in mortality from 2000 to 2004 indicates that these improvements in outcomes were due to effective therapy $[30,31,38]$. Indeed, the therapeutic monoclonal antibody, rituximab, was introduced into clinical use in Australia initially for patients with relapsed or refractory indolent B-cell NHL (follicular or small lymphocytic subtypes) in 1998, and then for patients with diffuse large B-cell lymphoma (the commonest type of aggressive NHL) in early 2002. The use of rituximab for treating Bcell NHL has been wide spread in Australia (Figure 3) as universal health coverage is available and, consistent with findings from clinical trials, the improved survival was mainly seen in B-cell lymphomas and was of a similar magnitude to that reported in the trials [23,39]. It is likely that these 5-year relative survival estimates in 2000-2004 derived by period analysis underestimate the true later observed relative survival [40] given the rapid increase in the use of rituximab for treatment of NHL in Australia. Taking all this into account, we are reasonably confident that the introduction of rituximab is a major contributor to the improved survival observed in 2000-2004.

Our results are also consistent with other populationbased studies examining trends in NHL survival over time $[41,42]$. In a recent study using data from the Surveillance, Epidemiology, and End Results (SEER) program, Pulte et al found that 5-year relative survival for NHL patients in the United States improved significantly between 1990-92 and 2002-2004 (from 50.4\% to 66.8\%) [41]. The apparent greater improvement in survival observed by Pulte et al [41] over the same time period as our study may be explained by the shorter time intervals used for their analysis (three years, not five years) with the greatest benefits from the use of rituximab occurring in the most recent period. However, the overall consistency of these results with those we reported during an almost identical study period provides indirect confirmation of our findings. The improved survival in 2000-2004 we observed was also comparable to that of a populationbased study in Canada [42]. However, the magnitude of the survival improvement that we observed was more modest. This may be due to the fact that they excluded patients with poor prognosis such as those who were HIV positive and those who did not receive curative treatment 


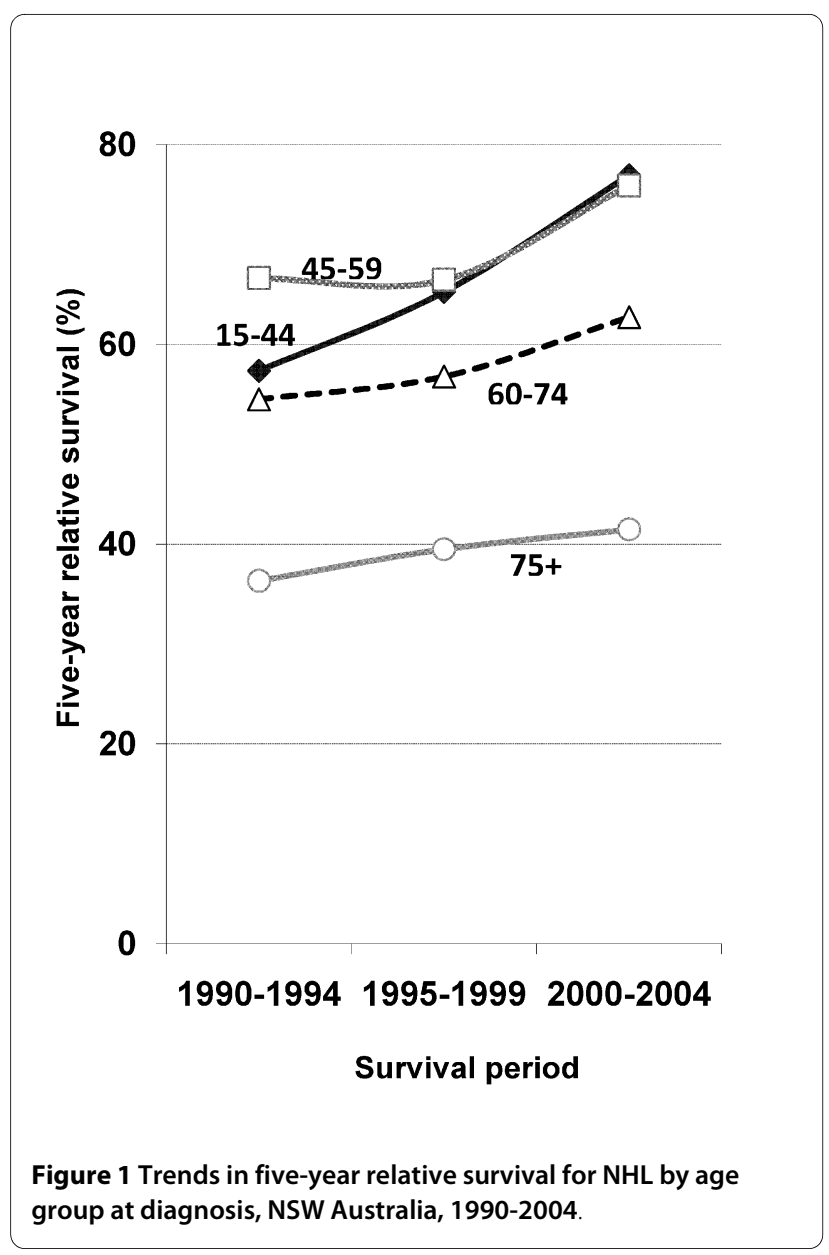

[42] whereas our study included all patients with aggressive NHL.

Age at diagnosis was inversely associated with survival (Figure 1) which is probably due to more co-morbidities and adverse effects of chemotherapy in older patients.

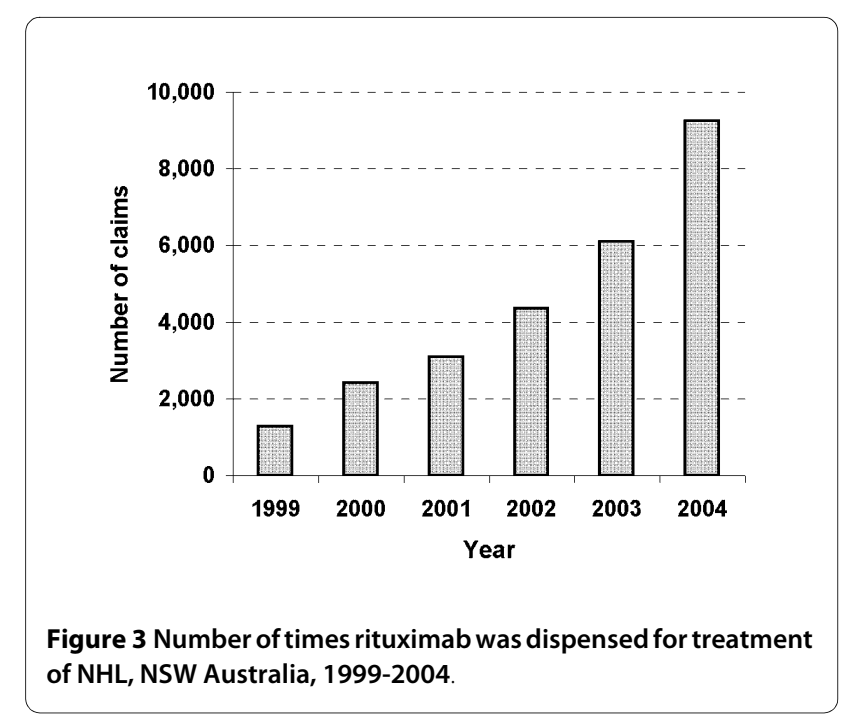

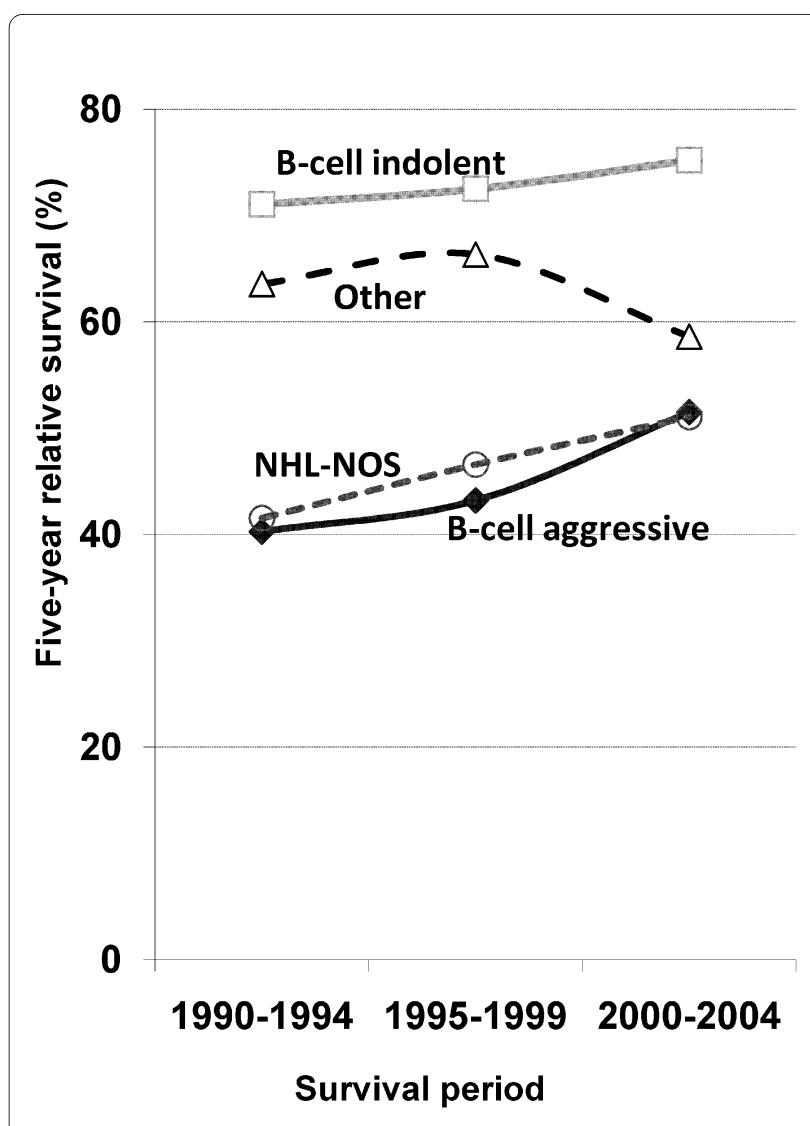

Figure 2 Trends in five-year relative survival for NHL by histological subtype, NSW Australia, 1990-2004.

However, the improved survival over time was seen for both older and younger patients (Figure 1), although it was less for those very old (75+ years). This is consistent with evidence from clinical trials: survival increased for both older (60-80 years) [23] and younger (18-60 years) patients [35] after the addition of rituximab to standard chemotherapy for aggressive B-cell lymphomas, the commonest NHL subtype.

The relative survival trends for NHL NOS and aggressive B-cell lymphomas were similar (Figure 2). This suggests that the former group of patients also received rituximab because previous studies showed that patients who did not receive cancer-related therapy had poorer outcomes $[43,44]$. Improved diagnostic specificity during the 1990s [45] did not decrease the proportion of NOS lymphomas over time (Table 2). This is very similar to the results of a previous study where a SEER registry was reviewed by an expert hematopathologist (24.3\% vs $25 \%)$ [46] and suggests that it may not be possible to decrease this proportion further on a population-based cancer registry.

The data used in this study have some limitations. The cancer registry does not collect detailed treatment infor- 
mation and so the data do not allow us to directly conclude that the survival benefit observed over time was due to the use of rituximab in the treatment of NHL, although the Pharmaceutical Benefits claims data (Figure 3) provided indirect support for the observed improved survival in 2000-2004. However, these data do not allow us to estimate the fraction of patients diagnosed in 20002004 who actually used rituximab, thus the possibility that some unmeasured factors mentioned earlier might also have contributed to this improved survival cannot be ruled out completely. Another limitation was that the cancer registry does not collect information on patients' comorbidities and disease extent for NHL. These factors are related to the prognosis for NHL [44]. However, our use of relative survival to account for competing mortality addressed these factors at least in part.

\section{Conclusions}

The observed rise in survival together with a fall in mortality from 2000 and a rapid increase in the use of rituximab, suggests that the benefit of adding rituximab to the standard treatment of NHL may have been experienced at least in part by this Australian NHL patient population. There are good grounds for believing that further improvement in survival, especially for patients with aggressive B-cell lymphomas, will almost certainly continue to increase as more follow-up time accrues.

\section{Competing interests}

The authors declare that they have no competing interests.

\section{Authors' contributions}

XQY designed the study, obtained the cancer registry data, provided oversight of the data analysis, and drafted the manuscript. WHC participated in the design of the study, performed the data analysis, and helped to draft the Methods and Results sections. DLO participated in the study design, obtained the prescription data, and revised the manuscript critically. All authors read and approved the final version of the manuscript.

\section{Acknowledgements}

This study was completed while Xue Qin Yu was employed by the American Cancer Society. We thank the NSW Central Cancer Registry for providing the data for this study and Ms Hui You for extracting further data for the revised paper. The Registry is managed by the Cancer Institute NSW under an agreement with the NSW Department of Health. These analyses were assisted by the SAS code and detailed documentation available from Paul Dickman's homepage http://www.pauldickman.com/. Xue Qin Yu is supported by an Australian National Health \& Medical Research Council Training Fellowship (550002)

\section{Author Details \\ 'Cancer Epidemiology Research Unit, Cancer Council New South Wales, 153 Dowling Street, Woolloomooloo, NSW 2011, Australia and 2InforMH, Mental Health and Drug and Alcohol Office, Macquarie Hospital, North Ryde NSW 2113, Australia}

Received: 5 August 2009 Accepted: 24 May 2010

Published: 24 May 2010

\section{References}

1. Molina A: A decade of rituximab: improving survival outcomes in nonHodgkin's lymphoma. Annu Rev Med 2008, 59:237-250.
2. Fisher Rl, Gaynor ER, Dahlberg S, Oken MM, Grogan TM, Mize EM, Glick JH, Coltman CA Jr, Miller TP: Comparison of a standard regimen (CHOP) with three intensive chemotherapy regimens for advanced nonHodgkin's lymphoma. N Eng/J Med 1993, 328(14):1002-1006.

3. Australian Drug Evaluation Committee - 197th meeting recommendations [http://www.tga.gov.au/docs/html/adec/ adec0197.htm]

4. Australian Drug Evaluation Committee - 220th meeting recommendations [http://www.tga.gov.au/docs/html/adec/ adec0220.htm]

5. Tracey E, Alam N, Chen W, Bishop J: Cancer in New South Wales: Incidence and Mortality 2006. Sydney: Cancer Institute NSW; 2008.

6. Medicare Australia: PBS Statistics [http://www.medicare.gov.au/ provider/pbs/stats.jsp]

7. Berkson J, Gage RP: Calculation of survival rates for cancer. Proc Staff Meet Mayo Clin 1950, 25(11):270-286.

8. Coleman M, Aylin P, (eds): Death certification and mortality statistics: an international perspective. 1st edition. London: The Stationery Office; 2000

9. Ederer $F$, Axtell LM, Cutler SJ: The relative survival rate: a statistical methodology. Natl Cancer Inst Monogr 1961, 6:101-121.

10. Chiang C: Introduction to stochastic processes in biostatistics. New York: Wiley; 1968.

11. Brenner $\mathrm{H}$, Gefeller $\mathrm{O}$ : An alternative approach to monitoring cancer patient survival. Cancer 1996, 78(9):2004-2010.

12. Dickman PW: Estimating and modelling relative survival using SAS. [http://www.pauldickman.com/rsmodel/sas colon/].

13. Plosker GL, Figgitt DP: Rituximab: a review of its use in non-Hodgkin's lymphoma and chronic lymphocytic leukaemia. Drugs 2003, 63(8):803-843

14. Morton LM, Turner JJ, Cerhan JR, Linet MS, Treseler PA, Clarke CA, Jack A Cozen W, Maynadie M, Spinelli JJ: Proposed classification of lymphoid neoplasms for epidemiologic research from the Pathology Working Group of the International Lymphoma Epidemiology Consortium (InterLymph). Blood 2007, 110(2):695-708.

15. Jaffe E, Harris N, Stein H, Vardiman J: World Health Organization Classification of Tumors: Pathology and Genetics of Tumors of Haematopoietic and Lymphoid Tissues. Lyon, France: IARC Press; 2001

16. Fritz A, Percy C, Jack A, Shanmugaratnam K, Sobin L, Parkin D, Whelan S, (eds): International Classification of Diseases for Oncology. 3rd edition. Geneva, Switzerland: World Health Organisation; 2000.

17. Percy C, Van Holten V, Muir C, (eds): International classification of diseases for oncology. 2nd edition. Geneva, Switzerland: World Health Organisation; 1990.

18. Yu XQ, O'Connell DL, Gibberd RW, Coates AS, Armstrong BK: Trends in survival and excess risk of death after diagnosis of cancer in 1980-1996 in New South Wales, Australia. Int J Cancer 2006, 119(4):894-900.

19. Dickman PW, Sloggett A, Hills M, Hakulinen T: Regression models for relative survival. Stat Med 2004, 23(1):51-64

20. Yu XQ, O'Connell DL, Gibberd RW, Smith DP, Dickman PW, Armstrong BK: Estimating regional variation in cancer survival: a tool for improving cancer care. Cancer Causes Control 2004, 15(6):611-618.

21. Kim HJ, Fay MP, Feuer EJ, Midthune DN: Permutation tests for joinpoint regression with applications to cancer rates. Stat Med 2000, 19(3):335-351

22. Statistical Research and Applications Branch NCl: Joinpoint Regression Program. 3.3th edition. 2008.

23. Coiffier B, Lepage E, Briere J, Herbrecht R, Tilly H, Bouabdallah R, Morel P, Neste E Van Den, Salles G, Gaulard P: CHOP chemotherapy plus rituximab compared with $\mathrm{CHOP}$ alone in elderly patients with diffuse large-B-cell lymphoma. N Eng/J Med 2002, 346(4):235-242.

24. Forstpointner R, Dreyling M, Repp R, Hermann S, Hanel A, Metzner B, Pott C, Hartmann F, Rothmann F, Rohrberg R: The addition of rituximab to a combination of fludarabine, cyclophosphamide, mitoxantrone (FCM) significantly increases the response rate and prolongs survival as compared with FCM alone in patients with relapsed and refractory follicular and mantle cell lymphomas: results of a prospective randomized study of the German Low-Grade Lymphoma Study Group. Blood 2004, 104(10):3064-3071.

25. Hiddemann W, Kneba M, Dreyling M, Schmitz N, Lengfelder E, Schmits R, Reiser M, Metzner B, Harder H, Hegewisch-Becker S: Frontline therapy with rituximab added to the combination of cyclophosphamide, 
doxorubicin, vincristine, and prednisone (CHOP) significantly improves the outcome for patients with advanced-stage follicular lymphoma compared with therapy with $\mathrm{CHOP}$ alone: results of a prospective randomized study of the German Low-Grade Lymphoma Study Group. Blood 2005, 106(12):3725-3732.

26. Cronin DP, Harlan LC, Clegg LX, Stevens JL, Yuan G, Davis TA: Patterns of care in a population-based random sample of patients diagnosed with non-Hodgkin's lymphoma. Hematol Oncol 2005, 23(2):73-81.

27. Hiddemann W, Longo DL, Coiffier B, Fisher Rl, Cabanillas F, Cavalli F, Nadler LM, de Vita VT, Lister TA, Armitage JO: Lymphoma classification--the gap between biology and clinical management is closing. Blood 1996, 88(11):4085-4089.

28. Clarke CA, Undurraga DM, Harasty PJ, Glaser SL, Morton LM, Holly EA: Changes in cancer registry coding for lymphoma subtypes: reliability over time and relevance for surveillance and study. Cancer Epidemiol Biomarkers Prev 2006, 15(4):630-638.

29. Dickman PW, Adami HO: Interpreting trends in cancer patient survival. $J$ Intern Med 2006, 260(2):103-117.

30. Karim-Kos HE, de Vries E, Soerjomataram I, Lemmens V, Siesling S, Coebergh JW: Recent trends of cancer in Europe: a combined approach of incidence, survival and mortality for 17 cancer sites since the 1990s. Eur J Cancer 2008, 44(10):1345-1389.

31. Sant M, Francisci S, Capocaccia R, Verdecchia A, Allemani C, Berrino F: Should we use incidence, survival or mortality to assess breast cancer trends in European women? Nat Clin Pract Oncol 2006, 3(5):228-229.

32. Pfreundschuh $M$, Trumper $L$, Kloess $M$, Schmits R, Feller AC, Rube $C$, Rudolph C, Reiser M, Hossfeld y, Eimermacher H: Two-weekly or 3-weekly CHOP chemotherapy with or without etoposide for the treatment of elderly patients with aggressive lymphomas: results of the NHL-B2 trial of the DSHNHL. Blood 2004, 104(3):634-641.

33. Johnson PW: Survival from non-Hodgkin lymphoma in England and Wales up to 2001. Br J Cancer 2008, 99(Suppl 1):S107-S109.

34. Wolf M, Bentley M, Marlton P, Horvath N, Lewis ID, Spencer A, Herrmann R, Arthur C, Durrant S, van Kerkhoven M: Pegfilgrastim to support CHOP-14 in elderly patients with non-Hodgkin's lymphoma. Leuk Lymphoma 2006, 47(11):2344-2350

35. Pfreundschuh M, Trumper L, Osterborg A, Pettengell R, Trneny M, Imrie K, Ma D, Gill D, Walewski J, Zinzani PL: CHOP-like chemotherapy plus rituximab versus $\mathrm{CHOP}$-like chemotherapy alone in young patients with good-prognosis diffuse large-B-cell lymphoma: a randomised controlled trial by the MabThera International Trial (MInT) Group. Lancet Oncol 2006, 7(5):379-391.

36. Grulich AE, Li Y, McDonald AM, Correll PK, Law MG, Kaldor JM: Decreasing rates of Kaposi's sarcoma and non-Hodgkin's lymphoma in the era of potent combination anti-retroviral therapy. AIDS 2001, 15(5):629-633.

37. Spina M, Carbone A, Vaccher E, Gloghini A, Talamini R, Cinelli R, Martellotta $F$, Tirelli U: Outcome in patients with non-hodgkin lymphoma and with or without human immunodeficiency virus infection. Clin Infect Dis 2004, 38(1):142-144

38. Sant M, Francisci S, Capocaccia R, Verdecchia A, Allemani C, Berrino F: Time trends of breast cancer survival in Europe in relation to incidence and mortality. Int J Cancer 2006, 119(10):2417-2422.

39. Marcus R, Imrie K, Belch A, Cunningham D, Flores E, Catalano J, SolalCeligny P, Offner F, Walewski J, Raposo J: CVP chemotherapy plus rituximab compared with CVP as first-line treatment for advanced follicular lymphoma. Blood 2005, 105(4):1417-1423.

40. Brenner $\mathrm{H}$, Hakulinen $\mathrm{T}$ : Advanced detection of time trends in long-term cancer patient survival: experience from 50 years of cancer registration in Finland. Am J Epidemio/ 2002, 156(6):556-577.

41. Pulte $\mathrm{D}$, Gondos $\mathrm{A}$, Brenner $\mathrm{H}$ : Ongoing improvement in outcomes for patients diagnosed as having Non-Hodgkin lymphoma from the 1990s to the early 21st century. Arch Intern Med 2008, 168(5):469-476.

42. Sehn LH, Donaldson J, Chhanabhai M, Fitzgerald C, Gill K, Klasa R, MacPherson N, O'Reilly S, Spinelli JJ, Sutherland J: Introduction of combined CHOP plus rituximab therapy dramatically improved outcome of diffuse large B-cell lymphoma in British Columbia. J Clin Oncol 2005, 23(22):5027-5033.

43. Cronin-Fenton DP, Sharp L, Deady S, Comber H: Treatment and survival for non-Hodgkin's lymphoma: influence of histological subtype, age, and other factors in a population-based study (1999-2001). Eur J Cancer 2006, 42(16):2786-2793.
44. Berrios-Rivera JP, Fang S, Cabanillas ME, Cabanillas F, Lu H, Du XL: Variations in chemotherapy and radiation therapy in a large nationwide and community-based cohort of elderly patients with nonHodgkin lymphoma. Am J Clin Oncol 2007, 30(2):163-171.

45. A clinical evaluation of the International Lymphoma Study Group classification of non-Hodgkin's lymphoma. The Non-Hodgkin's Lymphoma Classification Project. Blood 1997, 89(11):3909-3918.

46. Clarke CA, Glaser SL, Dorfman RF, Bracci PM, Eberle E, Holly EA: Expert review of non-Hodgkin's lymphomas in a population-based cancer registry: reliability of diagnosis and subtype classifications. Cancer Epidemiol Biomarkers Prev 2004, 13(1):138-143.

\section{Pre-publication history}

The pre-publication history for this paper can be accessed here: http://www.biomedcentral.com/1471-2407/10/231/prepub

doi: 10.1186/1471-2407-10-231

Cite this article as: Yu et al., Improved survival for non-Hodgkin lymphoma patients in New South Wales, Australia BMC Cancer 2010, 10:231

\section{Submit your next manuscript to BioMed Central and take full advantage of:}

- Convenient online submission

- Thorough peer review

- No space constraints or color figure charges

- Immediate publication on acceptance

- Inclusion in PubMed, CAS, Scopus and Google Scholar

- Research which is freely available for redistribution

Submit your manuscript at www.biomedcentral.com/submit
C) Biomed Central 